\title{
Skill Gap amongst MBA Graduates
}

\author{
${ }^{1}$ Prof.Prajakta Dhuru, ${ }^{2}$ Dr. S. Ramachandran \\ ${ }^{I}$ Research Scholar, Pacific University (PAHERU), Udaipur \\ ${ }^{2}$ Research Guide, Pacific University, Udaipur
}

\begin{abstract}
Management education today has undergoing a lot of turmoil. It has lost its importance and is largely looked at as a one of the basic degree of employment. Earlier management graduates enjoyed the attention of the corporate world and could carve their careers by progressing in the industry. But today, management degree does not ensure skill and employment. This study is an attempt to study the conceptual background of the gap. The study contributes in understanding various reasons behind the skill gap which is widely seen across the industry.
\end{abstract}

Keywords: management education, skill gap, employability

\section{Management Education an Introduction}

One of the most challenging tasks is placing the right person in the right job. One wrong decision can mean a lost productivity for organizations. Management graduates are hired by organizations with a preconceived belief that they are competent to demonstrate technical and managerial competencies to help them achieve the required goals and objectives. These managerial competencies have an impact on the performance of organization (Lucia, Dagmar, \& Milos, 2010).

Students enroll for management courses with the expectation that they will obtain the desired knowledge, skill and abilities to enter the corporate. They expect that the skills they quip in management schools will not only help them to perform in their respective domain areas, but also help them advance in their careers.

Management education is changing with times. Primary objective of management education is to prepare people to be outstanding managers and leaders (Boyatzis, Stubbs \& Taylor, 2002). Students have more exposure in enhancing their knowledge not only through classroom learning but also through social networks, job recruiters, media, and interactions with CEO's and VP's. On the other hand the curriculums are evolving thereby ensuring that students have maximum industrial interaction through field trips, consulting projects, intern projects than the typical classroom study which earlier has a prominent presence in their academic calendar. Management institutes claim to develop qualities and help the students gain more than the threshold knowledge to become effective managers and leaders (Boyatzis, 1982). To be an effective manager a person needs the ability to use knowledge and to make things happen. Management education has to be a combination of knowledge, Inspiration and Ethical Strength to every Individual, which would enable him or her to lead a proper professional and cultural life in Society. But today, it has been noticed that our Management Education has been successful in producing Graduates and Post Graduates in quantity rather than in Quality. Quality of knowledge is hardly taken care of in many Business Schools and Management Institution.

\section{Organizational Expectations}

Organizations today believe in acquiring talent that will give them a competitive advantage as it continues to move toward globalization. In today's knowledge economy, the industry expects that education system will provide the graduates with the desired employability skills to perform the job (Bok, 2006).Availability of employable and skilled workforce is paramount to economic development. In high population growth countries like

(C) 2019, IJSMS

Page 62 
China and India the rate of change of employability defines the rate of economic growth (Guo et al., 2008). While employment is the key to life, employability is the key to succeeding in qualifying for employment (Berntson, 2008). Employability has been given various definitions over the last 50 years. For the purpose of understanding, we look at the definition given by Harvey (2011). This says that employability is the ability of the individual to get a satisfying job. Earlier Pollard and Hillage (1998) said that it is the ability of the individual to move self-sufficiently in the labor market to realize potential through sustainable employment.

According to Datar, Garvin, \& Cullen, MBA's are deficient in global perspective, leadership skills, integration skills, recognizing organizational realities and implementing effectively, acting creatively and innovatively, thinking critically and communicating clearly, understanding the role, responsibilities and purpose of business, understanding the limits of models and markets (Datar, Garvin, \& Cullen, 2010). In the absence of these skills, it is difficult for MBA students to gain employability. This is extended by the NASSCOM's report (2012) specifying that not more than 25 per cent of engineers and MBA graduates are employable.

\section{Gap Identification}

Practicing managers visiting management institutions for recruitment as well as managers in the corporate sector, who manage/supervise recruits from management institute, often comment on the inadequacy of the management graduates' capabilities for taking up roles in organizations. According to Morrison (2012), 'A competent person should not be chosen lightly, because he or she needs to be qualified to identify the hazards associated with a particular operation.' An oft-heard comment from managers is that there is need to bridge the gap between the set of competencies and level of competencies which management graduates possess on completion of studies and those which industry needs

The educational process in business schools is continually criticized for failing to equip students with employability skills (Bennis and O'Toole, 2005; Neubaum et al., 2009; Pfeffer and Fong, 2004). This failure can be subdivided into two broad categories: first, the irrelevance of the management theory being taught (Chia and Holt, 2008; Ghoshal, 2005; Starkey et al., 2004); and second, the outdated processes used to teach the students (Bennis and O'Toole, 2005; Mintzberg, 2004; Pfeffer and Fong, 2004).

It is essential to reevaluate what set of knowledge, skills, and attitudes a professional need in order to succeed in the speedily changing global economy. Organizations have greater opportunities of succeeding in the market by ensuring competitiveness amongst the workforce.

Cappelli (2008) witnessed that organizations are now focusing on training employees with basic employability skills so that they can function in a series of jobs. Even the management graduates have a feeling that additional training is needed to develop systems thinking skills, while the faculty strongly felt that more emphasis on critical thinking skills is very important. On the other hand, the human resource managers felt that additional training of management skills is very important.

A number of studies have focused on identifying gaps viz., academic and business expectations regarding the "skills" and "personal attributes" necessary to achieve "employability" (Gelsdorf, 1986; Levenburge, 1996; McFadden et al., 1999 and Junghagen, 2005). Various studies to identify the "skills" and "personal attributes", that employers' value in graduates, have been undertaken (Powell and Posner, 1983; Atkins and Kent, 1988; Kanungo and Misra, 1992; Maes et al., 1997; Yorke, 2004; and Yorke and Harvey, 2005). Whilst important "skills" and personal attributes have been identified, the outcomes have been seen as a little too vague and a little too difficult to measure in terms of specific industry or organizational needs. Thus supporting, Van Der Heijden's (2002) concerns mentioned earlier. Nevertheless; Harvey (2005) notes, graduates are more likely to meet "employability" expectations than non-graduates. 
A GAP between the Management Education provided by the Institutes \& the actual expectation from the Corporate can be bridged. Management Education has become big business across the world today .Global Management Education market is estimated to be around USD 22 billion. This gives an overview of the changing scenario of the Management Education. Management Education has become a Business and almost all the Marketing strategies are being applied Branding has made inroads into Management Education.

With the changing organizational set ups and the ever evolving field of management studies it has become very important to identify if there lies any gap between the competencies expected by the organizations as against the actual competencies demonstrated by the management graduates in the organizational setting. This is an area where there does not seem to be sufficient rigorous research. What are the competencies which recruiting organizations look for when they recruit management graduates? What has been the past experience of recruitee with the competency levels of new recruits from management schools? What are the areas where there are the largest gaps between industry's expectations and the available competencies?

The highly dynamic environment of the business world impacted with forces of liberalization, worldwide competition, fast changing technologies, and new business models has made it necessary to identify what do corporate look at when they hire management graduates. What do corporate experience with these fresh graduates when they recruit these graduates? According to All India for Technical Education (AICTE), 354421 students enrolled for MBA in 3364 institutions across the country in 2014. According to them, the numbers of management institutions have risen from 2614 in 2006-07 to 3364 in 2013-14. While the number continuously rose till 2011-12, at least 71 institutes shut shop in 2012-13 and 107 in 2013-14. (TOI article dated Jan 12, $2015-12.59$ am) This suggests that though the quantity MBAs rose, the government and AICTE are compromising on the quality. This has resulted in huge gap in the employability of management graduates. According to the study of National skill Qualification framework (MSQF), in 2015-2016, out of 83306 students qualifying MBAs only 69226 are placed. This shows that this year around $14080 \mathrm{MBAs}$ are unemployed. These figures prove the fact mere certification is not the only criteria for employment. According to J Philip, former director of IIM-Bengaluru, the requirement of managerial candidates in the Indian market is between 35000 and 40000 every year.

According to ASSOCHAM, in their study by the ASSOCHAM Education Committee (AEC) noted only 7 $\%$ of the pas-outs are employable. Their study suggests that at least $5500 \mathrm{~B}$-schools in operation now, and other unapproved institutes only $7 \%$ of the graduates are employable. Around $200 \mathrm{~B}$-schools have shut down in major cities and 120 more expected to wing up in 2016. Students spend 3-5 lakh on a two-year MBA program; their current salary is merely 8000-10000. It is notices that the quality of IIM/IIT students coming out now are has come down as compared to those in past 15 years.

The above figures suggest that there is a dearth of research in this area and demands an in depth study to identify the why there exists a gap between the demand and supply of competencies. What have the corporate experienced earlier when they recruited these graduates? What are the various areas in managerial competencies where the gaps have emerged from?

\section{Further Scope of Research}

Further study is suggested to concentrate more on assessing the gaps between the actual levels of competencies demonstrated by the management students as against the desired level.

To develop insights into the extent of the gap between the demand and supply of the competencies of management graduates further study will help identify the positive and negative aspects of management education vis-à-vis the needs of industry. Such findings will provide significant information that will enable a review of 
curricula in management schools as well as pedagogy. Addressing these gaps through changes in the content and pedagogy would enable management institutes cater better to the needs of industry, thereby reducing the skepticism which managers in industry may have of newly recruited management graduates. It would also be a good feedback about what they need to do to develop students who are better ready to take up jobs in industry.

Analysis shows that MBA marketplace is changing as is society's perception of the roles, requirements and responsibilities of business leaders. A number of management schools have already moved to fill these gaps; those that stand par, we believe, run the risk of losing their standing and student appeal. There is a growing imperative of change. If the business schools hop to continue to thrive, they must respond far more empathetically than they did in the past.

Business schools should emphasize on balancing of technical and managerial skills while working on developing the curriculum for MBA program. Increase in analytical capability of graduates with academic performance should be balanced with developing student's managerial skills, attitudes and sense of purpose or identity. The schools must move on in improving teaching of thinking, reasoning, and creative problem-solving skills and focusing more attention on issues of accountability, ethics, and social responsibility. Also to ensure teaching by 'doing' and 'being', B-schools continue to experiment with and commit to new pedagogies and techniques, especially those that involves action learning, field experiences and reflective exercises. The wider the array of experiments, the more successful business schools are likely to be in tackling these challenges.

B-schools also need to understand the barriers that stand their way of continued changes in MBA education. The most difficult challenges are systemic and economic. They involve questions of how best to change the mix and motives of students so as to attract a new breed of applicants and more diverse portfolio of recruiters; and how best to overcome the high costs of curricula that accompany extensive small group experiences, intensive global exposure, personalized advising and feedback.

\section{REFERENCES}

[1] Basic employability skills: a triangular design approach: Stuart Rosenberg, Ronald Heimler, Elsa-Sofia Morote

[2] Bok, D. (2006), Our Underachieving Colleges, Princeton University Press, Princeton, NJ.

[3] Guo, Z. and van Heijden, B.I.J. (2008), "Employability enhancement of business graduates in China: reacting upon challenges of globalization and labour market demands", EducationpTraining, Vol. 50 No. 4, pp. 289-304.

[4] Harvey, L. (2011), Employability and Diversity, Centre for Research and Evaluation, Sheffield Hallam University.

[5] Pollard, E. and Hillage, J. (1998), Employability: Developing A Framework For Policy Analysis, Institute forEmployment Studies.

[6] Datar, S.M., David, A.G., \& Cullen, P.G.(2010). Rethinking the MBA, Boston Massachusetts, Harvard Business Press.

[7] As student employability is at the top of business schools' agendas (Bhanugopan and Fish, 2009; Hay, 2008; Mihail and Elefterie, 2006),

[8] Bennis, W. and O’Toole, J. (2005), "How business schools lost their way”, Harvard BusinessReview, Vol. 83 No. 5, pp. 96-104.

[9] Neubaum, D.O., Pagell, M., Drexler, J.A., Mckee-Ryan, F.M. and Larson, E. (2009), "Businesseducation and its relationship to student personal moral philosophies and attitudes toward profits: an empirical response to critics", The Academy of Management Learning and Education, Vol. 8 No. 1, pp. 9-24.

[10] Chia, R. and Holt, R. (2008), “The nature of knowledge in business schools”, Academy ofManagement Learning \& Education, Vol. 7 No. 4 , pp. 471-86. 
International Journal of Science and Management Studies (IJSMS)

Volume: 2 Issue: 5
September to October 2019
E-ISSN: 2581-5946

www.ijsmsjournal.org

[11] Ghoshal, S. (2005), "Bad management theories are destroying good management practices",Academy of Management Learning \& Education, Vol. 4 No. 1, pp. 75-91.

[12] Starkey, K., Hatchuel, A. and Tempest, S. (2004), "Rethinking the business school”, Journal ofManagement Studies, Vol. 41 No. 8, pp. 1521-31.

[13] Mintzberg, H. (2004), Managers not MBAs: A Hard Look at the Soft Practice of Managing andManagement Development, Financial Times Prentice Hall, London.

[14] Pfeffer, J. and Fong, C.T. (2004), “The business school 'business': some lessons from the USexperience”, Journal of Management Studies, Vol. 41 No. 8, pp. 1501-20.

[15] Cappelli, P. (2008), “Talent management for the twenty-first century”, Harvard Business Review, Vol. 86 No. 3, pp. 74-81.

[16] Gelsdorf, J.W. (1986), “Executives' and academics' perceptions on the need for instruction inwritten persuasion”, The Journal of Business Communication, Vol. 23 No. 4, pp. 55-68.

[17] Levenburge, N.M. (1996), “General management skills: do practitioners and academic facultyagree on their importance?", Journal of Education for Business, Vol. 72 No. 1, pp. 47-51.

[18] McFadden, K.L., Jansen, B. and Towell, E.R. (1999), "Building OM curriculum for the newmillennium: industry perceptions", MidAmerican Journal of Business, Vol. 14 No. 2,pp. 37-45.

[19] Junghagen, S. (2005), "Working with business and industry to enhance curriculum developmentand student employability", New Directions for Institutional Research, No. 128, pp. 69-81.

[20] Powell, G.N. and Posner, B.Z. (1983), "Stereotyping by college recruiters”, Journal of CollegePlacement, Vol. 44 No. 1, pp. 63-5.

[21] Atkins, C.P. and Kent, R.L. (1988), “What do recruiters consider important during theemployment interview?”, Journal of Employment Counselling, Vol. 25 No. 3, pp. 98-103.

[22] Kanungo, R.N. and Misra, S. (1992), "Managerial resourcefulness: a reconceptualization ofmanagement skills", Human Relations, Vol. 45 No. 12, pp. 1311-33.

[23] Maes, J.D., Weldy, T.G. and Icengogle, M.L. (1997), “A managerial perspective:oral communication competency is most important for business students in theworkplace”, The Journal of Business Communication, Vol. 34 No. 1, pp. 67-79.

[24] Yorke, M. (2004), "Employability in the undergraduate curriculum: some student perspectives",European Journal of Education, Vol. 39 No. 4, pp. 409-27.

[25] Yorke, M. and Harvey, L. (2005), "Graduate attributes and their development”, New Directions forInstitutional Research, No. 128, pp. 4158.

[26] Van der Heijden, B. (2002), "Prerequisites to guarantee life-long employability”, PersonnelReview, Vol. 31 No. 1, pp. 44-61.

[27] Harvey, L. (2005), "Embedding and integrating employability”, New Directions for InstitutionalResearch, No. 128, pp. 13-28.

[28] ZENITH International Journal of Multidisciplinary Research Vol.2 Issue 2, February 2012, ISSN 22315780 www.zenithresearch.org.in 368 Restructuring Management Education Today, For Better Tomorrow Neelam Sheoliha*; Sudeep Kumar** 